\begin{tabular}{|c|c|}
\hline Title & Cholic acid accumulation and its diminution by short-chain fatty acids in bifidobacteria \\
\hline Author(s) & Kurdi, Peter; Tanaka, Hiroshi; W. van V een, Hendrik; A sano, Kozo; Tomita, Fusao; Y okota, A tsushi \\
\hline Citation & $\begin{array}{l}\text { Microbiology, 149, 2031-2037 } \\
\text { https://doi.org/10.1099/mic.0.26376-0 }\end{array}$ \\
\hline Issue Date & 2003 \\
\hline Doc URL & http:/hdl .handle.net/2115/5422 \\
\hline Type & article \\
\hline File Information & M49.pdf \\
\hline
\end{tabular}

Instructions for use 


\section{Cholic acid accumulation and its diminution by short-chain fatty acids in bifidobacteria}

\begin{abstract}
Correspondence
Atsushi Yokota

yokota@chem.agr.hokudai.ac.jp
\end{abstract}

Received 29 March 2003

Accepted 28 April 2003

\author{
Peter Kurdi, ${ }^{1}$ Hiroshi Tanaka, ${ }^{2} \dagger$ Hendrik W. van Veen, ${ }^{3} \ddagger$ Kozo Asano, ${ }^{4}$ \\ Fusao Tomita ${ }^{4}$ and Atsushi Yokota ${ }^{5}$
}

\author{
${ }^{1}$ Northern Advancement Center for Science \& Technology, Kita 7 Nishi 2, Kita-ku, Sapporo \\ 060-0807, Japan \\ ${ }^{2}$ Snow Brand Milk Products Co., Ltd, 1-1-2, Minamidai, Kawagoe 350-1165, Japan \\ ${ }^{3}$ Department of Microbiology, Groningen Biomolecular Sciences and Biotechnology Institute, \\ University of Groningen, 9751 NN Haren, The Netherlands \\ ${ }^{4,5}$ Laboratory of Applied Microbiology ${ }^{4}$, and Laboratory of Microbial Resources and Ecology ${ }^{5}$, \\ Division of Applied Bioscience, Graduate School of Agriculture, Hokkaido University, Kita 9 \\ Nishi 9, Kita-ku, Sapporo 060-8589, Japan
}

\begin{abstract}
Cholic acid (CA) transport was investigated in nine intestinal Bifidobacterium strains. Upon energization with glucose, all of the bifidobacteria accumulated CA. The driving force behind CA accumulation was found to be the transmembrane proton gradient $(\Delta \mathrm{pH}$, alkaline interior). The levels of accumulated CA generally coincided with the theoretical values, which were calculated by the Henderson-Hasselbalch equation using the measured internal $\mathrm{pH}$ values of the bifidobacteria, and a $\mathrm{p} K_{\mathrm{a}}$ value of $6 \cdot 4$ for $\mathrm{CA}$. These results suggest that the mechanism of CA accumulation is based on the diffusion of a hydrophobic weak acid across the bacterial cell membrane, and its dissociation according to the $\Delta \mathrm{pH}$ value. A mixture of short-chain fatty acids (acetate, propionate and butyrate) at the appropriate colonic concentration (117 $\mathrm{mM}$ in total) reduced CA accumulation in Bifidobacterium breve JCM $1192^{\top}$. These short-chain fatty acids, which are weak acids, reduced the $\Delta \mathrm{pH}$, thereby decreasing CA accumulation in a dose-dependent manner. The bifidobacteria did not alter or modify the CA molecule. The probiotic potential of $\mathrm{CA}$ accumulation in vivo is discussed in relation to human bile acid metabolism.
\end{abstract}

\section{INTRODUCTION}

Bile, which is produced by liver cells, is composed mainly of bile salts, and is secreted into the duodenum via the bile duct. Bile salts are glycine and taurine conjugates of bile acids, and act as natural ionic detergents. In the intestine, the bile salts play an essential role in emulsifying lipids, which enables intra-luminal lipolysis and the absorption of lipolytic products by enterocytes. Cholic acid (CA) is one of the most common free bile acids in the intestine, and is produced mostly by the deconjugation of bile salts, such as taurocholic acid and glycocholic acid. Deconjugation is carried out by the bile salt hydrolases (BSHs) of the indigenous members of the genera Bacteroides (Masuda, 1981),

†Present address: Ciphergen Biosystems K.K., Yokohama 240-0005, Japan.

‡Present address: Department of Pharmacology, University of Cambridge, Tennis Court Road, Cambridge CB2 1PD, UK.

Abbreviations: $\mathrm{BSH}$, bile salt hydrolase; $\mathrm{CA}$, cholic acid; cFSE, carboxyfluorescein succinimidyl ester; $\mathrm{DiSC}_{3}(5), 3,3$ '-dipropylthiadicarbocyanine iodide; SCFA, short-chain fatty acid.
Bifidobacterium (Tanaka et al., 1999), Clostridium (Masuda, 1981) and Lactobacillus (Tanaka et al., 1999). The free bile acids are further modified by various intestinal microorganisms to produce secondary bile acids, such as deoxycholic acid and lithocholic acid (Baron \& Hylemon, 1997; Kitahara et al., 2000).

Within the human intestinal microbiota, the lactobacilli and bifidobacteria have attracted much attention with regard to their potential probiotic effects. Although many Lactobacillus and Bifidobacterium species have been associated with various health-promoting and beneficial properties (Ouwehand et al., 2002), their interactions with free bile acids are not well characterized. The growth inhibition of intestinal bacteria by free bile acids has been demonstrated (Binder et al., 1975), but the effects of free bile acids on the physiology of intestinal bacteria have not been elucidated. In our previous reports (Kurdi et al., 2000; Yokota et al., 2000), we showed that Lactococcus lactis actively extrudes CA from the cell in an ATP-dependent manner, whereas various Lactobacillus species from the intestine, dairy products and other environments are 
capable of accumulating CA when they are energized by glucose. The mechanism underlying CA accumulation seems to be not transporter-mediated, but depends on the diffusion of hydrophobic CA across the bacterial cell membrane according to the transmembrane proton gradient $(\Delta \mathrm{pH}$, alkaline interior), which is formed upon energization with glucose. These findings led us to investigate the interactions of CA with bifidobacteria in the intestines of infants and healthy adults. In addition, we studied the effects on CA accumulation of short-chain fatty acids (SCFAs), which are normally present in the human large intestine as a mixture of acetate, propionate and butyrate.

\section{METHODS}

Bacterial strains. The Bifidobacterium strains used in this study (Table 1) were obtained from the Japan Collection of Microorganisms (JCM, Wako, Japan) and Snow Brand Milk Products Co. Ltd (SBT, Kawagoe, Japan). The Eubacterium lentum-like strain c-25 was kindly provided by Professor Dr Hiroshi Oda (Department of Bacteriology, Faculty of Medicine, Kagoshima University, Kagoshima, Japan).

\section{CA transport in Bifidobacterium spp.}

CA transport experiment. The bacteria were grown until midexponential phase in half-strength MRS ( $1 / 2$ MRS) broth (Difco) that was supplemented with $0 \cdot 25 \mathrm{~g} \mathrm{~L}$-cysteine/ $\mathrm{HCl}^{-1}$ under anaerobic conditions at $37^{\circ} \mathrm{C}$, using a mixed gas $\left(\mathrm{N}_{2} / \mathrm{CO}_{2} / \mathrm{H}_{2} ; 8: 1: 1\right)$. Preparation of the de-energized, washed cell suspension and the CA transport experiments were carried out essentially as described previously (Kurdi et al., 2000). The cells were harvested, washed with $50 \mathrm{mM}$ potassium phosphate $(\mathrm{pH} \mathrm{7.0}), 1 \mathrm{mM} \mathrm{MgSO}_{4}$ and $0.1 \mathrm{U}$ horseradish peroxidase $\mathrm{ml}^{-1}$ (Buffer 1), and de-energized with $10 \mathrm{mM}$ of 2-deoxyglucose in Buffer 1 that was supplemented with
$1 \cdot 0 \mathrm{U}$ horseradish peroxidase $\mathrm{ml}^{-1}$ (Buffer 2). The cells were washed three times with Buffer 1 to completely remove the 2-deoxyglucose and resuspended at $3 \mathrm{mg}$ protein $\mathrm{ml}^{-1}$ in $150 \mathrm{mM}$ potassium phosphate $(\mathrm{pH} 7 \cdot 0), 1 \mathrm{mM} \mathrm{MgSO}_{4}$ and $1 \cdot 0 \mathrm{U}$ horseradish peroxidase $\mathrm{ml}^{-1}$ (Buffer 3), to an $\mathrm{OD}_{660}$ value of approximately 10 . Buffer 3 was used to prevent substantial extracellular acidification, which would greatly affect the results of the transport experiment. It was confirmed that this buffer allowed a drop of only $0 \cdot 1$ of a $\mathrm{pH}$ unit in these experiments. The resulting cell suspension was equilibrated by stirring for $10 \mathrm{~min}$ from time 0 in $0 \cdot 116 \mathrm{mM}\left(16 \mathrm{mCi} \mathrm{mmol}^{-1}\right.$, $592 \mathrm{MBq} \mathrm{mmol}^{-1}$ ) [carboxyl- $\left.{ }^{14} \mathrm{C}\right] \mathrm{CA}$ (Perkin Elmer) at $37^{\circ} \mathrm{C}$ under anaerobic conditions (mixed gas). Under these conditions, once the cells were energized by $10 \mathrm{mM}$ (final concentration) glucose, $100 \mu \mathrm{l}$ samples were mixed with $3 \mathrm{ml}$ of Stop Buffer (Kurdi et al., 2000) and the samples were filtered quickly through $0.45 \mu \mathrm{m}$ cellulose acetate filters (Schleicher \& Schuell). The cells on the filters were immediately washed with $3 \mathrm{ml}$ of Stop Buffer using filtration. The membranes were placed into Eppendorf tubes, and the levels of radioactivity were counted in a scintillation counter after the addition of $1.4 \mathrm{ml}$ of the scintillation cocktail (Emulsifier Scintillator Plus; Perkin Elmer). The control cells (no added glucose) were treated with $2 \mu \mathrm{M}$ valinomycin and $1 \mu \mathrm{M}$ nigericin at time 0 , to ensure complete de-energization. A sample of the reaction mixture without cells was also measured as the background level, which was subtracted from each of the test readings.

When the effects of the SCFAs were examined, the sodium salts were added to a final concentration of $117 \mathrm{mM}$, i.e. $66 \mathrm{mM}$ acetate, $26 \mathrm{mM}$ propionate and $25 \mathrm{mM}$ butyrate. These concentrations approximate the respective levels of the acids in the ascending colon (Cummings, 1997). The effect of $39 \mathrm{mM}$ SCFAs with the same component ratio was also investigated, to check the dose response. The SCFA mixtures were added $8 \mathrm{~min}$ after energization with glucose; the addition of the SCFA mixtures did not change the $\mathrm{pH}$ of the medium.

Calculation of the accumulated CA. The absolute amount of $\mathrm{CA}$ that was associated with the cells was expressed in nmol (mg

Table 1. CA transport in Bifidobacterium strains

\begin{tabular}{|c|c|c|c|c|c|c|}
\hline \multirow[t]{2}{*}{ Strain } & \multirow[t]{2}{*}{ Origin } & \multicolumn{2}{|c|}{ CA amount $\left[\mathrm{nmol}(\mathrm{mg} \text { protein })^{-1}\right]^{\star}$ in } & \multicolumn{2}{|c|}{ Accumulation factor $\dagger$} & \multirow[t]{2}{*}{ Internal $\mathrm{pH} \S$} \\
\hline & & De-energized cells & Energized cells & Measured $^{\star}$ & Predicted $\ddagger$ & \\
\hline B. catenulatum JCM $1194^{\mathrm{T}}$ & Human faeces & $0 \cdot 83 \pm 0 \cdot 08$ & $2 \cdot 2 \pm 0 \cdot 25$ & $4 \cdot 9 \pm 0 \cdot 76$ & $3 \cdot 06$ & $7 \cdot 47$ \\
\hline B. pseudocatenulatum JCM $1200^{\mathrm{T}}$ & Faeces of infant & $0 \cdot 72 \pm 0 \cdot 34$ & $1 \cdot 4 \pm 0 \cdot 35$ & $2 \cdot 8 \pm 0 \cdot 14$ & $1 \cdot 75$ & $7 \cdot 20$ \\
\hline B. longum SBT-2928 & Human intestine & $0 \cdot 81 \pm 0 \cdot 25$ & $2 \cdot 1 \pm 1 \cdot 13$ & $4 \cdot 7 \pm 2 \cdot 47$ & $1 \cdot 75$ & $7 \cdot 20$ \\
\hline B. bifidum JCM 1254 & Intestine of adult & $0 \cdot 45 \pm 0 \cdot 21$ & $1 \cdot 5 \pm 0 \cdot 71$ & $4 \cdot 0 \pm 1 \cdot 56$ & $1 \cdot 94$ & $7 \cdot 25$ \\
\hline B. bifidum JCM $1255^{\mathrm{T}}$ & Faeces of infant & $0 \cdot 53 \pm 0 \cdot 01$ & $1 \cdot 5 \pm 0 \cdot 21$ & $3 \cdot 6 \pm 0 \cdot 64$ & $1 \cdot 94$ & $7 \cdot 25$ \\
\hline B. adolescentis JCM 7046 & Intestine of adult & $0 \cdot 55 \pm 0 \cdot 18$ & $1 \cdot 2 \pm 0 \cdot 14$ & $2 \cdot 7 \pm 0 \cdot 07$ & ND & ND \\
\hline
\end{tabular}

ND, Not determined.

${ }^{*}$ Results are shown as means \pm SD where $n=2$, except for JCM $1194^{\mathrm{T}}(n=3)$ and JCM $1192^{\mathrm{T}}(n=7)$.

$\dagger$ The ratio of the internal CA concentration to the external CA concentration. The external CA concentration was $0 \cdot 116 \mathrm{mM}$. The internal CA concentration was calculated on the assumption of $3 \mu \mathrm{l} \mathrm{(mg} \mathrm{protein)}{ }^{-1}$ internal volume (Poolman et al., 1987). CA amounts exceeding $0.35 \mathrm{nmol}(\mathrm{mg} \text { protein })^{-1}$ (corresponding to an accumulation factor of $1 \cdot 0$ ) in the de-energized (valinomycin- and nigericin-treated) cells were assumed to be due to non-specific binding, and these values were subtracted from the CA levels in the energized cells when calculating the accumulation factors (measured values).

$\ddagger$ Calculated using the Henderson-Hasselbalch equation and the measured internal $\mathrm{pH}$ values.

$\S$ Measured with the intracellularly conjugated fluorescent $\mathrm{pH}$ probe cFSE. 
protein $)^{-1}$. The CA accumulation factor, which is defined as the ratio of the internal CA concentration to the external CA concentration, was also calculated. Calculation of the internal CA concentration was based on the assumption of an internal cell volume of $3 \mu \mathrm{l}$ $(\mathrm{mg} \text { protein })^{-1}$ (Poolman et al., 1987). Non-specific binding of CA to the cell surface and/or to the cell membrane was estimated from the positive deviation of the calculated internal CA concentration of the control series (no glucose added; de-energized with ionophores) from the extracellular CA concentration of $0 \cdot 116 \mathrm{mM}$. The nonspecific binding value estimated in this way was subtracted from the calculated internal CA concentration values in the energized series. Thus, the accumulation factor was obtained from these corrected intracellular CA concentrations, where the accumulation factor for the control series was set at $1 \cdot 0$.

The protein content of the cell suspensions was determined using the DC Protein Assay Kit (Bio-Rad) according to the manufacturer's instructions and BSA as the standard. The cell suspensions were boiled for $5 \mathrm{~min}$ in $1 \mathrm{M} \mathrm{NaOH}$ and then centrifuged; the resulting supernatants were used in the assays.

Measurement of intracellular pH. Internal $\mathrm{pH}$ measurements were performed as described previously (Kurdi et al., 2000), using the internally conjugated fluorescent $\mathrm{pH}$ probe carboxyfluorescein succinimidyl ester (cFSE; Molecular Probes) (Breeuwer et al., 1996). Briefly, the cells were cultured until mid-exponential phase, harvested and washed twice in Buffer 1. The cells were resuspended to an $\mathrm{OD}_{660}$ value of approximately 0.5 in Buffer 3 and incubated at $37^{\circ} \mathrm{C}$ for $30 \mathrm{~min}$ in the presence of the precursor probe carboxyfluorescein diacetate succinimidyl ester. To eliminate unbound probe, the cells were incubated with glucose for $1 \mathrm{~h}$ and then washed once in Buffer 3. The cells were subsequently resuspended in Buffer 3, and the intracellular $\mathrm{pH}$ measurements were carried out. The effects of SCFAs on the internal $\mathrm{pH}$ were examined by the addition of SCFA mixtures at final total concentrations of 117 or $39 \mathrm{mM}$.

Transmembrane electrical potential $(\Delta \Psi)$ measurements. Changes in $\Delta \Psi$ during energization were monitored using the fluorescent dye 3,3'-dipropylthiadicarbocyanine iodide $\left[\operatorname{DiSC}_{3}(5)\right.$; Molecular Probes], which is a cationic probe that crosses the cell membrane, and the fluorescence of which is quenched as the membrane potential develops (negative interior). The harvested cells were washed twice with ice-cold Buffer 4 (Buffer 1 that contained $65 \mathrm{U}$ catalase $\mathrm{ml}^{-1}$ instead of peroxidase), then resuspended in Buffer 5 (Buffer 3 with $65 \mathrm{U}$ catalase $\mathrm{ml}^{-1}$ in place of peroxidase), to an $\mathrm{OD}_{660}$ value of approximately 10 , and stored on ice. The replacement of peroxidase with catalase was important for reproducible measurements of $\Delta \Psi$ in the bifidobacteria because (i) peroxidase quenched the fluorescence of the $\mathrm{DiSC}_{3}(5)$ probe, even before energization of the cells (see below), while catalase did not have this effect, and (ii) the addition of peroxidase or catalase was critical for bifidobacterial metabolism of glucose under experimental anaerobic conditions. The cells were added to a stirred cuvette that contained Buffer 5 (final $\mathrm{OD}_{660}$ value of $0 \cdot 05$ ) and $\mathrm{DiSC}_{3}(5)$ (final concentration of $0.5 \mu \mathrm{M})$. Glucose (10 mM final concentration) was then added under anaerobic conditions (mixed gas was introduced into the cuvette headspace), to energize the cells. Fluorescence measurements were performed with an LS50B fluorimeter (Perkin Elmer) with excitation and emission wavelengths of 651 and $675 \mathrm{~nm}$, respectively (slit widths of $4 \cdot 0 \mathrm{~nm}$ ).

CA metabolism by bifidobacteria. The Bifidobacterium strains were cultured in $3 \mathrm{ml}$ of $1 / 2$ MRS broth, as described in the transport experiment section, while the positive control, E. lentum-like strain c-25, was grown in GAM Broth 'Nissui' (Nissui Pharmaceutical). Both of these media contained $0 \cdot 15 \mathrm{mM}$ sodium cholate; the cultures were incubated for $48 \mathrm{~h}$ under anaerobic conditions (mixed gas). The culture broths were acidified with concentrated $\mathrm{HCl}$ to $\mathrm{pH} \mathrm{2,} \mathrm{and} \mathrm{the} \mathrm{bile} \mathrm{acids} \mathrm{were} \mathrm{extracted} \mathrm{with} \mathrm{ethyl} \mathrm{acetate.} \mathrm{The} \mathrm{bile}$ acids were separated by TLC using Silica gel 60 (Merck) and cyclohexane/ethyl acetate/acetic acid (7:23:3, v/v; Eneroth, 1963) as the solvent. The bile acid spots on the TLC plate were visualized by spraying with the colouring reagent $5 \%(\mathrm{w} / \mathrm{v})$ phosphomolybdic acid $\left\{\mathrm{H}_{3}\left[\mathrm{P}\left(\mathrm{Mo}_{3} \mathrm{O}_{10}\right)_{4}\right] \cdot n \mathrm{H}_{2} \mathrm{O}\right\}$, which was dissolved in ethanol, and then heated in an oven at $110^{\circ} \mathrm{C}$ for $10 \mathrm{~min}$.

\section{RESULTS}

\section{CA accumulation in Bifidobacterium cells}

The CA levels of Bifidobacterium breve JCM $1192^{\mathrm{T}}$ cells equilibrated between the external medium and the deenergized cells (Fig. 1a), since the hydrophobic protonated CA was able to diffuse freely across the cell membrane (Kamp \& Hamilton, 1993). The addition of glucose as a fermentable substrate energized the cells, after which the amount of CA in the cells started to increase, as compared to control cells that did not receive glucose (Fig. 1a). All of the tested bifidobacteria accumulated CA $[1 \cdot 2-3 \cdot 6 \mathrm{nmol}$ $(\mathrm{mg} \text { protein })^{-1}$, and none of the strains showed detectable CA extrusion when energized with glucose (Table 1). The apparent (i.e. measured) CA accumulation factor, which was defined as the ratio of the internal CA concentration to the external concentration, was between 2.7 and 8.5 (Table 1). These values were similar to those observed for lactobacilli (Kurdi et al., 2000). In addition, we measured the CA transport in B. breve JCM $1192^{\mathrm{T}}$ at $1 \cdot 0$ and $2 \cdot 0 \mathrm{mM}$ external CA concentrations, and observed CA accumulation factors of about 5 and 4, respectively (data not shown).

\section{Bioenergetics of CA accumulation}

The observation that CA accumulation is an energydependent process led us to investigate the contribution of the components of the proton motive force, $\Delta \Psi$ and $\Delta \mathrm{pH}$, to CA accumulation. Therefore, we studied the effects of valinomycin (dissipates $\Delta \Psi$ ) and nigericin (abolishes $\Delta \mathrm{pH}$ ) on CA accumulation in bifidobacteria. The results of these experiments using B. breve JCM $1192^{\mathrm{T}}$ and Bifidobacterium bifidum JCM $1255^{\mathrm{T}}$ (data not shown) revealed that the addition of $2 \mu \mathrm{M}$ valinomycin increased the amount of accumulated CA (Fig. 1a), as compared to the control energized cells that were not treated with valinomycin. However, the addition of $1 \mu \mathrm{M}$ nigericin reduced the amount of accumulated CA in the energized cells to the equilibration level (Fig. 1a). These observations indicate that the $\mathrm{pH}$ gradient $(\Delta \mathrm{pH})$ is the driving force behind CA accumulation.

To further confirm the involvement of $\Delta \mathrm{pH}$ in the accumulation process, the internal $\mathrm{pH}$ of the JCM $1192^{\mathrm{T}}$ cells was measured with the fluorescence probe cFSE (Fig. 1b). The internal $\mathrm{pH}$ started to increase (from $\mathrm{pH} 7 \cdot 15$ to around $\mathrm{pH} 7 \cdot 5) 5 \mathrm{~min}$ after energization by glucose. This $\mathrm{pH}$ level was maintained until the addition of ionophores. The formation of the $\Delta \mathrm{pH}$ coincided with CA accumulation 

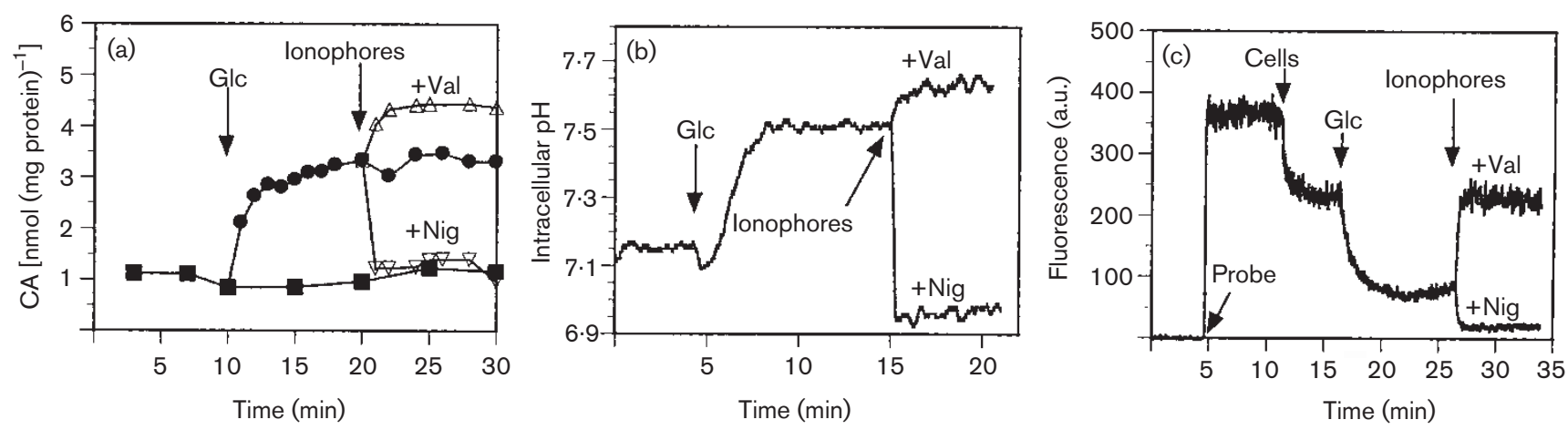

Fig. 1. CA transport (a) follows the kinetics of the internal $\mathrm{pH}$ changes (b), but not those of the membrane potential (c) when ionophores are added to energized $B$. breve JCM $1192^{\top}$ cells. (a) De-energized, washed cells were incubated with $0 \cdot 116 \mathrm{mM}$ [carboxyl- ${ }^{14} \mathrm{C}$ ]CA in the absence $(\boldsymbol{\square})$ or in the presence of $10 \mathrm{mM}$ glucose $(\mathrm{Glc}, \boldsymbol{O})$. lonophores, valinomycin (Val, $\triangle$ ) and nigericin $(\mathrm{Nig}, \nabla)$ were added to the energized cells at final concentrations of 2 and $1 \mu \mathrm{M}$, respectively. (b) The cells $\left(\mathrm{OD}_{660} \sim 0.5\right)$ were pre-loaded with cFSE and energized with $10 \mathrm{mM}$ Glc for approximately $10 \mathrm{~min}$, before the addition of Val or Nig at final concentrations of 5 or $200 \mathrm{nM}$, respectively. (c) Washed cells were added $\left(\mathrm{OD}_{660} \sim 0.05\right)$ to the cuvette that contained the $\operatorname{DiSC}_{3}(5)$ probe $(0.5 \mu \mathrm{M})$. The cells were energized with Glc $(10 \mathrm{mM})$ for about 10 min, followed by the addition of $\mathrm{Val}(5 \mathrm{nM})$ or $\mathrm{Nig}(200 \mathrm{nM})$. The fluorescence intensity is expressed in arbitrary units (a.u.). All the experiments were carried out at an external $\mathrm{pH}$ of $7 \cdot 0$. The data shown are representative of at least three experiments that gave similar results.

(Fig. 1a). The addition of valinomycin resulted in an increase in the internal $\mathrm{pH}$, while the addition of nigericin abolished $\Delta \mathrm{pH}$ (Fig. 1b). These changes in internal $\mathrm{pH}$ and $\Delta \mathrm{pH}$ may be responsible for the alteration of accumulated CA levels in the JCM $1192^{\mathrm{T}}$ cells upon the addition of ionophores (Fig. 1a).

Monitoring of the changes of $\Delta \Psi$ using $\operatorname{DiSC}_{3}$ (5) (Fig. 1c) revealed that the development of $\Delta \Psi$ upon energization with glucose and CA accumulation occurred simultaneously. However, nigericin addition increased the $\Delta \Psi$, while valinomycin addition totally abolished it. These results clearly demonstrate that the $\Delta \mathrm{pH}$ component and not the $\Delta \Psi$ component of the proton motive force is the driving force behind the CA accumulation process.

Measurements of the internal $\mathrm{pH}$ values of eight Bifidobacterium strains with cFSE revealed a positive correlation between the CA accumulation factors and the internal $\mathrm{pH}$ values of the respective strains (Table 1 ). The higher the $\mathrm{pH}$ gradient (i.e. $\Delta \mathrm{pH}$ ), the higher the accumulation factor in most cases, which confirms that $\Delta \mathrm{pH}$ is the driving force behind CA accumulation. The theoretical accumulation factors, which were calculated from the measured internal $\mathrm{pH}$ values using the HendersonHasselbalch equation $\left(\mathrm{pH}=\mathrm{p} K_{\mathrm{a}}+\log \left[\mathrm{A}^{-}\right] /[\mathrm{HA}]\right.$, where the $\mathrm{p} K_{\mathrm{a}}$ of CA was $6 \cdot 4$ ), were lower than the actual accumulation factors (Table 1). It is possible that active CA transporters contributed to the CA accumulation in certain strains (e.g. JCM $1192^{\mathrm{T}}$ ) that had large differences between their measured and predicted accumulation factors. However, in strains with smaller differences between their predicted and measured accumulation factors, CA may have accumulated solely as the result of diffusion through the membrane, followed by $\Delta \mathrm{pH}$-dependent dissociation.

\section{Effect of SCFAs on CA accumulation}

Various mixtures of sodium acetate, sodium propionate and sodium butyrate, at final total concentrations of $117 \mathrm{mM}$ (which corresponds to the concentration of these SCFAs in the ascending colon) or $39 \mathrm{mM}$, were used to test the effect of SCFAs on CA accumulation. CA accumulation in JCM $1192^{\mathrm{T}}$ cells was reduced by at least $50 \%$ in the presence of the $117 \mathrm{mM}$ SCFA mixture (Fig. 2a), as compared to cells that were incubated in the absence of SCFAs, while the $39 \mathrm{mM}$ SCFA mixture produced a less pronounced reduction $(\sim 20 \%)$ in CA accumulation. The addition of nigericin further decreased $\mathrm{CA}$ accumulation, which suggests that a certain $\Delta \mathrm{pH}$ level was maintained in the JCM $1192^{\mathrm{T}}$ cells in the presence of $117 \mathrm{mM}$ SCFAs. These SCFAs are weak acids with $\mathrm{p} K_{\mathrm{a}}$ values of $4 \cdot 75,4 \cdot 87$ and $4 \cdot 81$ for acetic, propionic and butyric acid, respectively. These weak acids, as is the case with CA, can be accumulated in bacterial cells (Russell, 1991), and can theoretically reduce the internal pH of bacterial cells (Diez-Gonzalez \& Russell, 1997). As expected, measurements of the internal $\mathrm{pH}$ changes of energized JCM $1192^{\mathrm{T}}$ cells upon the addition of the SCFA mixtures revealed decreases in the internal pH (Fig. 2b, c). The $\Delta \mathrm{pH}$ levels were reduced by about 60 and $22 \%$ by the addition of SCFA mixtures at $117 \mathrm{mM}$ (Fig. 2b) and $39 \mathrm{mM}$ (Fig. 2c), respectively. These reductions correspond to the reductions in the amounts of accumulated CA in JCM $1192^{\mathrm{T}}$ cells following treatment with the SCFA mixtures. These results indicate that in the presence of SCFAs, acidification 

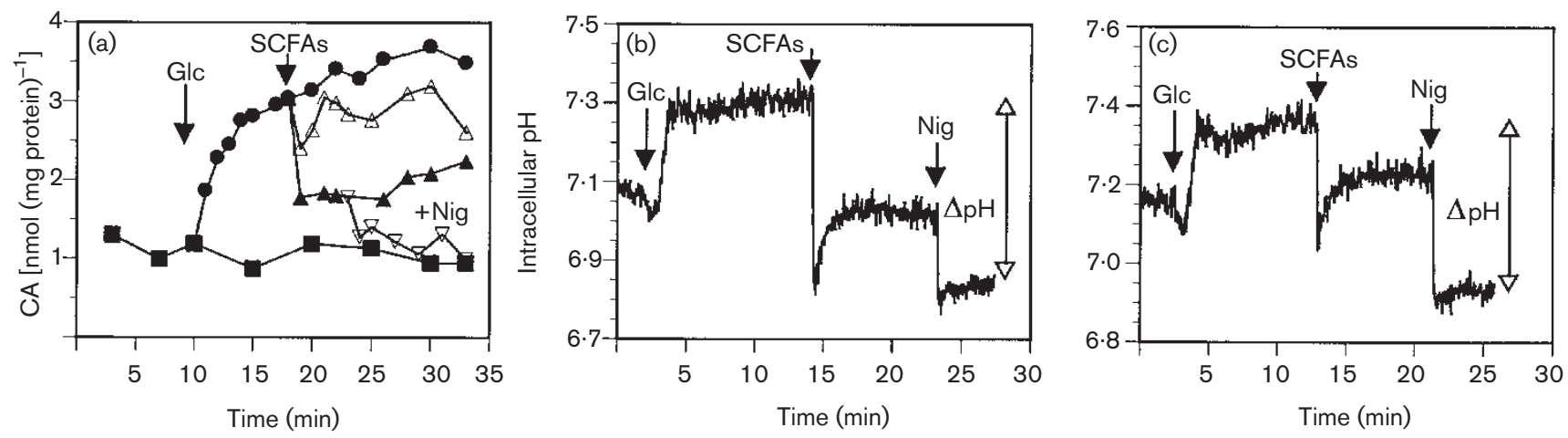

Fig. 2. SCFA mixtures impair CA transport and reduce the internal $\mathrm{pH}$ of $B$. breve JCM $1192^{\top}$. (a) De-energized, washed cells were incubated with $0 \cdot 116 \mathrm{mM}$ [carboxyl- $\left.{ }^{14} \mathrm{C}\right] \mathrm{CA}(\boldsymbol{\square})$, and then energized with $10 \mathrm{mM}$ glucose (Glc) in the absence $(\bullet)$ or in the presence of the SCFA mixtures. The SCFAs were applied at total concentrations of $117 \mathrm{mM}(\boldsymbol{\Delta}$; acetate $66 \mathrm{mM}$, propionate $26 \mathrm{mM}$, butyrate $25 \mathrm{mM})$ and $39 \mathrm{mM}(\triangle$; with the same component ratio). Nigericin (Nig, $\nabla)$ was added at a final concentration of $1 \mu \mathrm{M}$. (b, c) The internal $\mathrm{pH}$ measurements were performed as described in the legend to Fig. 1. SCFAs at concentrations of 117 and $39 \mathrm{mM}$ were used in (b) and (c), respectively. Nig was added at a final concentration of $200 \mathrm{nM}$. The magnitude of $\Delta \mathrm{pH}$ is indicated. All of the experiments were conducted at an external $\mathrm{pH}$ of $7 \cdot 0$. The data shown are representative of at least three experiments that gave similar results.

of the intracellular environment and the subsequent decrease in $\Delta \mathrm{pH}$ reduce CA accumulation.

\section{CA metabolism by bifidobacteria}

Although our experiments demonstrate that CA is accumulated spontaneously in energized bifidobacterial cells, the possibility exists that bifidobacteria metabolize CA. To test this hypothesis, bile acids were extracted from whole culture broths, in which bifidobacteria had been incubated with CA for $48 \mathrm{~h}$, and analysed using the TLC method. As shown in Fig. 3, none of the Bifidobacterium strains used in the transport experiments produced deoxycholic acid or any other metabolite of CA, while deoxycholic acid formation was confirmed in the E. lentum-like strain c-25.

\section{DISCUSSION}

To date, there has been little information on the interactions between free bile acids and bifidobacteria, which are considered to be the most important indigenous bacteria in the large intestine, in terms of their abundance and health-promotion properties (Mitsuoka, 2002). Although one might anticipate that intestinal bacteria have active mechanisms for the extrusion of growth inhibitory compounds, such as bile acids, this notion is not consistent with our observations. We found that bifidobacteria do not have apparent bile acid extrusion activities. On the contrary, energized cells accumulate CA (Fig. 1a, Table 1). This activity is very similar to that described in lactobacilli (Kurdi et al., 2000). Bile acid transport was studied in Lactococcus lactis, which can actively export CA via a multi-specific organic anion transporter, which is driven by ATP (Yokota et al., 2000), while Escherichia coli utilizes the energy of the

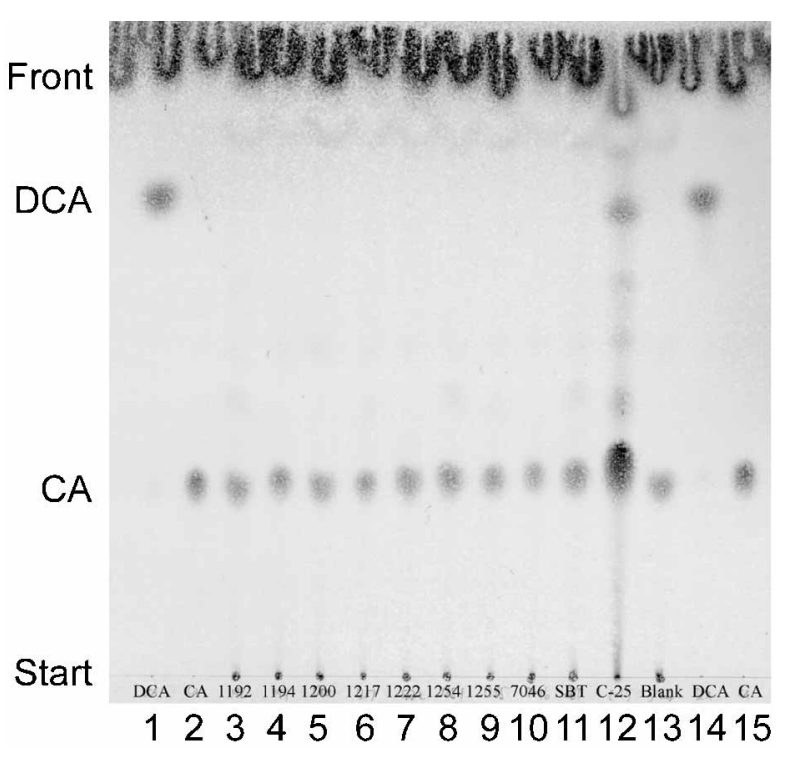

Fig. 3. Bifidobacteria do not metabolize CA. Thin-layer chromatogram of whole-cell extracts from $48 \mathrm{~h}$-old cultures of various Bifidobacterium strains. The strains were cultured in the presence of $0.15 \mathrm{mM}$ sodium cholate. Lanes: 1 and 14 , deoxycholic acid (DCA); 2 and 15, CA; 3, B. breve JCM 1192 ${ }^{\top} ; 4$, B. catenulatum JCM $1194^{\top} ; 5, B$. pseudocatenulatum JCM $1200^{\top} ; 6$, B. longum JCM $1217^{\top} ; 7$, B. infantis JCM $1222^{\top}$; 8, B. bifidum JCM 1254; 9, B. bifidum JCM 1255 ${ }^{\top} ; 10$, B. adolescentis JCM 7046; 11, B. longum SBT-2928; 12, Eubacterium lentum-like strain c-25 (positive control); 13, blank (no strain was inoculated into the medium). The results shown are representative of at least three experiments that gave similar results. 
proton motive force to extrude chenodeoxycholic acid and taurocholate (Thanassi et al., 1997). Another intestinal microbe, Clostridium scindens (formerly known as Eubacterium sp. VPI 12708; Kitahara et al., 2000), takes up CA using the proton motive force (Mallonee \& Hylemon, 1996) for the dehydroxylation of the CA molecule at the seventh carbon atom (White et al., 1980). A gene from Lactobacillus johnsonii 100-100 was identified that encodes an importer that takes up taurocholate for the intracellular BSH reaction (Elkins \& Savage, 1998). Moreover, this strain appeared to contain another gene for a putative conjugated bile acid transporter (Elkins et al., 2001).

As is the case in lactobacilli (Kurdi et al., 2000), the results presented here indicate that the driving force for CA accumulation in bifidobacteria is the $\Delta \mathrm{pH}$ component of the proton motive force, and not the $\Delta \Psi$ component (Fig. 1). We hypothesize that CA accumulation in bifidobacteria occurs in the following way. (i) The hydrophobic CA molecules diffuse into the cytoplasm of the energized bifidobacterial cell and dissociate according to the ratio given by the Henderson-Hasselbalch equation under the given cytoplasmic $\mathrm{pH}$ value. (ii) Since the cytoplasmic $\mathrm{pH}$ value is higher than that outside (i.e. $\Delta \mathrm{pH}$ ), more dissociation takes place in the cytoplasm than in the external medium. The resulting negatively charged cholate anions cannot pass the membrane due to their polarity, and thus they are trapped inside the cell. (iii) CA influx continues until the concentration of the protonated CA molecule equilibrates on both sides of the cell membrane. In this situation, the total amount of CA (the sum of the protonated and dissociated species) is higher in the cytoplasm than in the external medium. (iv) The intracellular concentration of CA remains higher than that of the external environment, until the cells are energized and the CA concentration gradient across the membrane disappears, along with the disappearance of $\Delta \mathrm{pH}$. It is worth mentioning that substantial discrepancies were observed in some strains between the values for the measured CA accumulation factors and the values that were predicted by the above mechanism, i.e. the latter values were lower than the former values. Therefore, we cannot discount the possibility that an active CA uptake mechanism (e.g. driven by $\Delta \mathrm{pH}$ ) exists.

SCFA production by intestinal bacteria is a very important process in the large intestine, and provides energy for enterocytes (Cummings \& Macfarlane, 1997). One of the major benefits of the fermentation of prebiotics is that it yields SCFAs (Cummings et al., 2001), which in turn decrease the intestinal $\mathrm{pH}$. CA accumulation was impaired when mixtures of SCFAs (117 or $39 \mathrm{mM}$ ) were added to the experimental reaction mixture (Fig. 2), although the residual amounts of accumulated CA in these cells were clearly higher than those found in the non-energized control cells. The presence of SCFAs at the physiological concentrations found in the colon appears to exert a severe environmental stress, from the bioenergetical standpoint, on bifidobacterial cells. Even in the presence of SCFAs, CA accumulation may occur in energized Bifidobacterium cells, and this process may operate in vivo. This hypothesis was strengthened by our results which indicate that $B$. breve JCM $1192^{\mathrm{T}}$ accumulated CA even when external CA concentrations were 1.0 and $2.0 \mathrm{mM}$ (around its physiological concentrations; estimated from Ewe \& Karbach, 1989). Moreover, CA accumulation at $1.0 \mathrm{mM}$ external CA concentration was observed in JCM $1192^{\mathrm{T}}$ cells even in the presence of $117 \mathrm{mM}$ SCFAs by a factor of $2 \cdot 4$ (data not shown).

Our experiments on CA metabolism by bifidobacteria revealed that Bifidobacterium strains were unable to chemically modify the CA molecule (Fig. 3), which is in agreement with a previous report (Takahashi \& Morotomi, 1994). This absence of any chemical modification of CA concurs with our hypothetical mechanism for CA accumulation, which suggests that $\mathrm{CA}$ accumulation by bifidobacteria results from the co-existence of a membrane $\Delta \mathrm{pH}$ and a weak acid in the same environment. The participation of a putative active CA uptake system appears to be unlikely, since the tested bifidobacteria did not utilize CA. Therefore, CA accumulation appears to be the result of energization.

The conjugated bile acid taurocholic acid is not accumulated in the BSH-negative Lactobacillus salivarius subsp. salicinius strain JCM 1044 (Kurdi et al., 2000) due to its hydrophilicity $\left(\mathrm{p} K_{\mathrm{a}}=1 \cdot 4\right)$. Thus, only unconjugated free bile acids are accumulated in lactobacilli and bifidobacteria. According to the published distributions of BSH activities, most of the bifidobacterial strains are BSH-positive (Tanaka et al., 1999). Therefore, in bifidobacteria, conjugated bile acids seem to be the source of free bile acids, which are supposed to be formed inside the cells from conjugated bile acids by BSH activities (Tanaka et al., 2000). It is possible that the CA that is formed from taurocholic acid and glycocholic acid is kept inside bifidobacterial cells in the intestine, for as long as the bacteria are energized.

One possible consequence of CA entrapment in bifidobacterial cells would be the decreased formation of deoxycholic acid in the large intestine. The bifidobacteria do not metabolize CA (Fig. 3; Takahashi \& Morotomi, 1994), and thus are unable to produce deoxycholic acid following CA accumulation. Deoxycholic acid and lithocholic acid, which are formed via $7 \alpha$-dehydroxylation from CA and chenodeoxycholic acid, respectively, by certain intestinal Clostridium and Eubacterium species (Baron \& Hylemon, 1997), are cytotoxic and possible tumour promoters (Reddy et al., 1976; Reddy \& Watanabe, 1979). Thus, the accumulation of CA may contribute to the decreased occurrence of colon carcinogenesis. Another possible impact of CA accumulation is a decrease in recycled CA during enterohepatic circulation due to the enhanced excretion of CA from the human host via the faeces. Under these conditions, the synthesis of bile acids from blood cholesterol increases, to compensate for the lost amounts of bile acids, thereby decreasing the blood cholesterol level. Although these features appear quite attractive, experimental evidence for 
the probiotic relevance of CA accumulation in bifidobacterial cells is lacking. Therefore, in vivo experiments that evaluate these possibilities are urgently needed.

\section{ACKNOWLEDGEMENTS}

The authors wish to thank Professor Dr W. N. Konings (Department of Microbiology, University of Groningen, The Netherlands) and Dr I. Mierau (NIZO Food Research, Ede, The Netherlands) for encouragement and valuable suggestions during the experiments. This work was partly funded by the Nestlé Science Promotion Committee. The authors thank the Radioisotope Laboratory of the Graduate School of Agriculture, Hokkaido University for CA transport experiments.

\section{REFERENCES}

Baron, S. F. \& Hylemon, P. B. (1997). Biotransformation of bile acids, cholesterol, and steroid hormones. In Gastrointestinal Microbiology, vol. 1, Gastrointestinal Ecosystems and Fermentations, pp. 470-510. Edited by R. I. Mackie \& B. A. White. New York: International Thomson Publishing.

Binder, H. J., Filburn, B. \& Floch, M. (1975). Bile acid inhibition of intestinal anaerobic organisms. Am J Clin Nutr 28, 119-125.

Breeuwer, P., Drocourt, J., Rombouts, F. M. \& Abee, T. (1996). A novel method for continuous determination of the intracellular $\mathrm{pH}$ in bacteria with the internally conjugated fluorescent probe 5 (and 6-)carboxyfluorescein succinimidyl ester. Appl Environ Microbiol 62, 178-183.

Cummings, J. H. (1997). Short-chain fatty acids. In The Large Intestine in Nutrition and Disease, pp. 43-65. Bruxelles: Institut Danone.

Cummings, J. H. \& Macfarlane, G. T. (1997). Role of intestinal bacteria in nutrient metabolism. Clin Nutr 16, 3-11.

Cummings, J. H., Macfarlane, G. T. \& Englyst, H. N. (2001). Prebiotic digestion and fermentation. Am J Clin Nutr 73, 415S-420S.

Diez-Gonzalez, F. \& Russell, J. B. (1997). Effects of carbonylcyanide$m$-chlorophenylhydrazone (CCCP) and acetate on Escherichia coli O157: H7 and K-12: uncoupling versus anion accumulation. FEMS Microbiol Lett 151, 71-76.

Elkins, C. A. \& Savage, D. C. (1998). Identification of genes encoding conjugated bile salt hydrolase and transport in Lactobacillus johnsonii 100-100. J Bacteriol 180, 4344-4349.

Elkins, C. A., Moser, S. A. \& Savage, D. C. (2001). Genes encoding bile salt hydrolases and conjugated bile salt transporters in Lactobacillus johnsonii 100-100 and other Lactobacillus species. Microbiology 147, 3403-3412.

Eneroth, P. (1963). Thin-layer chromatography of bile acids. J Lipid Res 4, 11-16.

Ewe, K. \& Karbach, U. (1989). Functions of the alimentary canal. In Human Physiology, pp. 693-734. Edited by R. F. Schmidt \& G. Thews. Berlin: Springer-Verlag.
Kamp, F. \& Hamilton, J. A. (1993). Movement of fatty acids, fatty acid analogues, and bile acids across phospholipid bilayers. Biochemistry 32, 11074-11086.

Kitahara, M., Takamine, F., Imamura, T. \& Benno, Y. (2000). Assignment of Eubacterium sp. VPI 12708 and related strains with high bile acid $7 \alpha$-dehydroxylating activity to Clostridium scindens and proposal of Clostridium hylemonae sp. nov., isolated from human faeces. Int J Syst Evol Microbiol 50, 971-978.

Kurdi, P., van Veen, H. W., Tanaka, H., Mierau, I., Konings, W. N., Tannock, G. W., Tomita, F. \& Yokota, A. (2000). Cholic acid is accumulated spontaneously, driven by membrane $\Delta \mathrm{pH}$, in many lactobacilli. J Bacteriol 182, 6525-6528.

Mallonee, D. H. \& Hylemon, P. B. (1996). Sequencing and expression of a gene encoding a bile acid transporter from Eubacterium sp. strain VPI 12708. J Bacteriol 178, 7053-7058.

Masuda, N. (1981). Deconjugation of bile salts by Bacteroides and Clostridium. Microbiol Immunol 25, 1-11.

Mitsuoka, T. (2002). Prebiotics and intestinal flora. Biosci Microflora 21, 3-12.

Ouwehand, A. C., Salminen, S. \& Isolauri, E. (2002). Probiotics: an overview of beneficial effects. Antonie van Leeuwenhoek 82, 279-289.

Poolman, B., Hellingwerf, K. J. \& Konings, W. N. (1987). Regulation of the glutamate-glutamine transport system by intracellular $\mathrm{pH}$ in Streptococcus lactis. J Bacteriol 169, 2272-2276.

Reddy, B. S. \& Watanabe, K. (1979). Effect of cholesterol metabolites and promoting effect of lithocholic acid in colon carcinogenesis in germ-free and conventional F344 rats. Cancer Res 39, 1521-1524.

Reddy, B. S., Narasawa, T., Weisburger, J. H. \& Wynder, E. L. (1976). Promoting effect of sodium deoxycholate on colon adenocarcinomas in germfree rats. J Natl Cancer Inst 56, 441-442.

Russell, J. B. (1991). Resistance of Streptococcus bovis to acetic acid at low $\mathrm{pH}$ : relationship between intracellular $\mathrm{pH}$ and anion accumulation. Appl Environ Microbiol 57, 255-259.

Takahashi, T. \& Morotomi, M. (1994). Absence of cholic acid $7 \alpha$-dehydroxylase activity in the strains of Lactobacillus and Bifidobacterium. J Dairy Sci 77, 3275-3286.

Tanaka, H., Doesburg, K., Iwasaki, T. \& Mierau, I. (1999). Screening of lactic acid bacteria for bile salt hydrolase activity. J Dairy Sci 82, 2530-2535.

Tanaka, H., Hashiba, H., Kok, J. \& Mierau, I. (2000). Bile salt hydrolase of Bifidobacterium longum - biochemical and genetic characterization. Appl Environ Microbiol 66, 2502-2512.

Thanassi, D. G., Cheng, L. W. \& Nikaido, H. (1997). Active efflux of bile salts by Escherichia coli. J Bacteriol 179, 2512-2518.

White, B. A., Lipsky, R. L., Fricke, R. J. \& Hylemon, P. B. (1980). Bile acid induction specificity of $7 \alpha$-dehydroxylase activity in an intestinal Eubacterium species. Steroids 35, 103-109.

Yokota, A., Veenstra, M., Kurdi, P., van Veen, H. W. \& Konings, W. N. (2000). Cholate resistance in Lactococcus lactis is mediated by an ATP-dependent multispecific organic anion transporter. J Bacteriol 182, 5196-5201. 